December 2017 Volume 5 Issue 10

www.joucer.com

http://dergipark.gov.tr/jcer

Research Article

\title{
Educational Administrators' Technological Leadership Efficacy and Perceptions towards Implementation Levels of Teaching and Learning Activities
}

\author{
Fatih ULUKAYA ${ }^{1}$ (D) , Nail YILDIRIM ${ }^{2}$ (D), Vildan ÖZEKE ${ }^{3 *}$ (D) \\ 1 Tokat Public Education Center and Evening Art School, Information Technologies Teacher, fatihulukaya@gmail.com \\ ${ }^{2}$ Gaziosmanpasa University, Faculty of Education, Educational Administration Department, nail.yildirim@gop.edu.tr \\ ${ }^{3}$ Gaziosmanpasa University, Faculty of Education, Computer Education and Instructional Technologies Depart., vildan.cevik@gop.edu.tr \\ * Corresponding Author: vildan.cevik@gop.edu.tr
}

Article Info

Received: $\quad$ February 16, 2017

Accepted: July 28, 2017

Online: $\quad$ December 03, 2017

Keywords: Leadership, technological leadership, teaching and learning activities, school administrators

\begin{abstract}
The aim of this study is to identify the educational administrators' technological leadership efficacy (TLE) and perceptions towards implementation levels of teaching and learning activities (ITLA), and then to present the contribution of the TLE as a predictor of the ITLA. We collected data from 112 educational administrators who are working in Tokat. According to the results of this study, educational administrators' TLE level was "adequate" for only Digital age learning culture, for the other factors and the total of the TLE levels were "intermediate" level. According to ITLA results, all the sub-factors and total of the scale were "strongly agree" level. The technological leadership efficacy and perceptions towards implementation levels of teaching and learning activities differ according to educational administrators' age, school type and working in town/city. There is a positive, medium level and significant correlation between educational administrators' total scores of the TLE and ITLA. A simple linear regression was calculated to predict administrators' perceptions towards implementation levels of teaching and learning activities based on their technological leadership efficacy, and TLE explains only $29 \%$ of the variation in ITLA.
\end{abstract}

To cite this article: Ulukaya, F., Yıldırım, N., \& Özeke, V. (2017). Okul yöneticilerinin teknoloji liderliği özyeterlikleri ile eğitim öğretim işlerini gerçekleştirme düzeylerine ilişkin algıları. Journal of Computer and Education Research, 5 (10), 125-149. https://doi.org/10.18009/jcer.292439

\section{Okul Yöneticilerinin Teknoloji Liderliği Özyeterlikleri ile Eğitim Öğretim İşlerini Gerçekleştirme Düzeylerine İlişkin Algıları}

\begin{tabular}{|c|c|}
\hline Makale Bilgisi & Öz \\
\hline $\begin{array}{lcc}\text { Geliş: } & \text { 16 Şubat } 2017 & \\
\text { Kabul: } & 28 \text { Temmuz } 2017 & \\
\text { Yayın: } & \text { 03 Aralık } 2017 & \\
& & \\
\text { Anahtar } & \text { kelimeler: } & \text { Liderlik, } \\
\text { teknoloji } & \text { liderliği, eğitim } & \text { öğretim } \\
\text { işleri, okul yöneticileri. } & \end{array}$ & $\begin{array}{l}\text { Bu çalışmanın amacı, okul yöneticilerinin teknoloji liderliği özyeterlikleri ile } \\
\text { eğitim öğretim işlerini gerçekleştirme düzeylerine ilişkin algıların belirlemek ve } \\
\text { teknoloji liderliği özyeterliklerinin eğitim öğretim işlerini gerçekleştirme } \\
\text { düzeyine katkısını ortaya koymaktır. Bu çerçevede Tokat ilinde görev yapan } 112 \\
\text { okul yöneticisine ulaşlmıştır. Araşırma bulguları incelendiğinde okul } \\
\text { yöneticilerinin teknoloji liderliği özyeterlik algılarının sadece dijital çağ öğrenme } \\
\text { kültürü boyutunda "yeterli düzeyde", diğer alt boyutlarda ve genel toplamda } \\
\text { ise "orta düzeyde" olduğu görülmüştür. Okul yöneticilerinin eğitim öğretim } \\
\text { işlerini gerçekleştirme düzeylerine ilişkin analiz sonuçları incelendiğinde, okul } \\
\text { yöneticilerinin araştırmanın tüm alt boyutlarında ve genel toplamda verdikleri } \\
\text { cevapların "çok katıllyorum" düzeyinde olduğu görülmüştür. Bu iki değişken, } \\
\text { yaş, okul türü ve il/ilçede çalışıor olma durumlarına göre farklılaşmaktadır. } \\
\text { Eğitim öğretim işleri gerçekleştirme düzeyleri toplamı ile teknoloji liderliği } \\
\text { özyeterlik algıları toplamı arasında da pozitif yönde, orta düzeyde ve anlamlı bir } \\
\text { ilişki görülmektedir. Eğitim öğretim işlerini gerçekleştirme düzeylerine ilişkin } \\
\text { varyansın \%29'unun okul yöneticilerinin teknoloji liderliği özyeterlik düzeyleri } \\
\text { ile açıklandığı görülmüştür. }\end{array}$ \\
\hline
\end{tabular}


December 2017 Volume 5 Issue 10

www.joucer.com

http://dergipark.gov.tr/jcer

\section{Summary}

\section{Educational Administrators' Technological Leadership Efficacy and Perceptions towards Implementation Levels of Teaching and Learning Activities}

In this study we aimed to identify the educational administrators' technological leadership efficacy (TLE) and perceptions towards implementation levels of teaching and learning activities (ITLA), and then to present the contribution of the TLE as a predictor of the ITLA. We collected data from 112 educational administrators who are working in Tokat by using the "Technological Leadership Self-Efficacy Scale for School Administrators" and "Teaching and Learning Activities Scale" as data collection tools. After obtaining the legal permissions, the data collection process was started in January 2014 and took for three months.

According to the results of this study, educational administrators' TLE level was "adequate" for only Digital age learning culture, for the other factors and the total of the TLE levels were "intermediate" level. While the highest TLE results were calculated in vocational school administrators, the lowest scores were calculated from elementary school administrators according to type of the schools. The administrators who are working in town had the higher scores than administrators who are working in the city in terms of "visionary leadership", "excellence in professional practice" and "total TLE" scores. The TLE scores did not differ significantly according to gender, age, education level and joining to in-service training before.

According to ITLA results, all the sub-factors and total of the scale were "strongly agree" level. The perceptions towards implementation levels of teaching and learning activities differ according to educational administrators' age and school type. For example, administrators in vocational schools got significantly higher scores in "Effectiveness and Coordinateness" factor than in elementary school administrators. According to the age of 
administrators; in terms of "Supporting services for development of instruction" and "Guidance services" factors, the between 20-34 ages group had the lowest perception scores. The ITLA scores did not differ significantly according to gender, working in town/city, education level and joining to in-service training before.

There is a positive, medium level and significant correlation between educational administrators' total scores of the technological leadership efficacy and perceptions towards implementation levels of teaching and learning activities. A simple linear regression was calculated to predict administrators' perceptions towards implementation levels of teaching and learning activities based on their technological leadership efficacy, and TLE explains only $29 \%$ of the variation in ITLA. 


\section{Giriș}

Okul yöneticilerinin teknolojik gelişmeleri kurumlarına entegre ederken ne düzeyde bilgili ve etkili oldukları oldukça önemlidir. Okul yöneticileri kendi sorumluluklarındaki okul ya da kurumları yeni teknolojiler ile uyumlu hale getirmelidir. Bununla birlikte tüm öğrencilerin bundan istifade edebilmesi için ilgi çekici eğitim ve sürekli dinamik bir öğrenme kültürü oluşturmalı ve bunu desteklemelidir. Bilgi ve teknoloji kaynaklarının etkili kullanılması konusunda, bu kaynakları kullanırken dikkat edilmesi gereken etik ve yasal konularla ilgili paydaşların bilgilendirilmesi ve denetlenmesi noktasında okul yöneticilerinin sorumlulukları vardır. Teknoloji konusunda yeterli bilgi ve becerisi olan bir okul yöneticisi çağın gerektirdiği tüm eğitim teknolojilerini kullanabilir ve bulunduğu kurumda bu teknolojilerin etkili biçimde kullanılması için uygun ortamları hazırlayabilir.

Eğitim yönetiminde bilişim teknolojileri ihmal edilerek, eğitim yönetimi ile bilgi yönetimi ve eğitim teknolojileri arasındaki işbirliğinin yeterince kurulamadığı düşünülmektedir (Telem, 1991). Okullarda teknolojinin izlenmesi, bilişim teknolojisi sınıf/laboratuvarlarının oluşturulması vb. sorumluluklarından dolayı okul yöneticilerine büyük sorumluluk düşmektedir. Bu çerçevede, okul yöneticileri bilişim teknolojileri alanında okullarındaki öğretmenlere ve öğrencilerine öncülük etmek ve teknoloji kullanımı konusunda onları yönlendirmek ve teşvik etmek gibi yeni sorumluluklar almak durumundadır. Bilgi teknolojilerinin okul yönetiminde ve sınıfta etkili kullanımı, hem okulun hem de bireysel üretkenliğin artırılmasında teknolojinin artan rolü, eğitim yöneticilerini teknolojideki yeni gelişmeleri takip etmeye ve güncel gelişmeleri okula yansıtmaya yönelik bazı yeterliklere sahip olmaya zorlamıştır (Turan, 2002). Geçmişle kıyaslandığında, günümüz teknoloji çağında başarılı olmak isteyen bir okul yöneticisinin sorumlulukları farklı alanlarda da uzmanlık gerektiren bir hal almıştır. Teknoloji konusunda yeteri düzeyde bilgi ve kabiliyete sahip olmak, liderlik rolünü bu alanda da sürdürmek, artık bir okul yöneticisinin olmazsa olmazları arasındadır.

Teknolojik altyapı ve hizmetlere ek olarak, okuldaki eğitim öğretim işlerinin yürütülmesi de okul yöneticilerinin diğer yükümlülükleridir. Okul yöneticisi bir taraftan teknolojiyi etkin kullanarak okuldaki eğitim öğretim işlerini gerçekleştirme sürecini de daha başarılı ve etkili kılabilir. Günümüzde teknolojik liderlik konusunda öz-yeterliği olmayan okul yöneticileri aynı zamanda eğitim öğretim işlerini gerçekleştirirken de sıkıntılar 
yaşayabilir. Bu iki bağlamın birbiriyle ilişkisini ortaya koyabilmek adına bu araştırmanın önemli olduğu düşünülmektedir.

Aksoy (2012)'a göre okul müdürünün yeterli olması ile okulun başarılı olması arasında bir ilişki vardır. Başarıll, becerikli, yetenekli, yetişmiş ve yeterli okul müdürlerinin başarılı okullar oluşturduğu düşünülmektedir. Bir kurum olarak okulun başarısının, onu yöneten okul müdürlerinin yeterlikleriyle ve okulda gerçekleştirilen eğitim-öğretim hizmetlerinin kalitesi ile ilgili olduğu düşünülmektedir. Bu süreci de yönlendirebilecek en etkili kişi olarak okul müdürlerinin yeterlikleri ile eğitim-öğretim süreci arasındaki ilişkinin önemli olduğu söylenebilir. Bu araştırmanın en önemli hedefi; okul yöneticilerinin teknoloji liderliği düzeyleri ve bu liderliklerinin eğitim öğretim işlerine yansımalarının ne düzeyde olduğunu ortaya koymaktır.

\section{Teknoloji Liderliği}

Çevik (2006)'e göre gelişen ve sürekli değişen çağımızda yeni teknolojilerin eğitimöğretim ortamlarına entegrasyonu ile gelecek nesillerimizi bilgi toplumu bireyi olarak yetiştirmek, okullarımızın temel amaçlarındandır. Bu kapsamda yöneticiler, okullarında eğitim ve teknolojinin kaynaşması ve uyumlu kullanımında liderlik misyonu yüklenmişlerdir. Deming (1998)'e göre lider güçlü bir öğrenme ortamı oluşturan, kişisel gelişimi teşvik eden kişidir. Eren (2007)'ye göre liderlik, bir grubu belirli bir amaç etrafında toplayabilme ve bu amaç için harekete geçirme yetenek ve bilgilerinin toplamıdır.

Teknolojinin çağa egemen olmasıyla beraber okul yöneticilerinin de kendilerini teknolojik gelişmelere uyarlamaları beklenmekte ve kendileri de bu konuda her geçen gün artan biçimde ihtiyaç hissettiklerini belirtmektelerdir (Hacıfazlıŏlu, Karadeniz \& Dalgıç, 2011a). Teknoloji lideri, çağın getirdiği yeniliklere ve gelişmelere uygun her türlü eğitim altyapısını kuran, yöneten, gerekli ortamı hazırlayan ve yararlanacak kimselerin eğitimini planlayıp motive ederek hazır hale getiren kişidir. Tanzer (2004) ise teknoloji liderini, çağın vazgeçilmez bir gerekliliği olan teknolojinin etkili ve maksimum verimlilik ile kullanılmasında gerekli eş yönlendirmeyi yapan, örgütü bu konuda etkileyen, yönlendiren ve yöneten kişi olarak tanımlamaktadır. Teknoloji lideri için yapılan tanımların birbirlerinden farklılık göstermesi, teknoloji liderinin rolünü ve sorumluluk alanlarını belirleyip bunları standartlaştırma ihtiyacını ön plana çıkarmıştır. Bu amaçla yapılan çalışmalar içerisinde ön plana çıkmış ve en kapsamlı çalışmalardan biri olan, Eğitimde Uluslararası Teknoloji Topluluğu yani yaygın olarak bilinen ismi ile ISTE (International 
Society for Technology in Education)'ye aittir (Hacıfazlığlu, Karadeniz \& Dalgıç, 2011b). Merkezi ABD'de bulunan ISTE ulusal teknoloji liderliği standartlarını Yöneticilere Yönelik Ulusal Eğitim Teknolojisi Standartları olarak belirlemiştir. Bu standartlar litaratürde NETS-A (National Educational Technology Standards for Administrators) olarak bilinmektedir. NETS-A ilk olarak 2001 yılının Kasım ayında açıklanmış olup, 2009 yılında bu standartlar revize edilerek NETS-A:2009 oluşturulmuştur. NETS-A standartlarının en belirgin ve önemli özelliği bütünlüklü bir projenin sonucunda ortaya çıkmış olmasıdır. Bu çerçevede hazırlanan ve öğrenci, öğretmen ve yöneticiler için belirlenmiş standartlar birbirleriyle uyumludur (Banoğlu, 2009).

NETS-A (2002)'da altı boyutta ele alınan standartlar NETS-A (2009) ile birlikte beş boyut şeklinde gruplanmıştır. 2009 yılında ISTE tarafından yeniden değerlendirilerek güncellenen yeni standartlara göre teknoloji liderinde aranan özellikleri Hacıfazlıŏlu, Karadeniz \& Dalgıç (2010) şöyle sıralamaktadır:

Vizyoner Liderlik. Eğitim yöneticileri, yönettikleri kurumun tamamında kapsamlı bir teknoloji entegrasyonu oluşturmak için mükemmelliği ve okuldaki dönüşümü destekleyen, herkes tarafından benimsenmiş ortak bir vizyonun geliştirilmesi ve bu vizyonun uygulanmasina ilham verir ve liderlik eder.

Dijital Çağ Öğrenme Kültürü. Eğitim yöneticileri, kurumlarında oluşturacakları dinamik bir dijital çağ öğrenme kültürü ile tüm öğrenciler için uygun, ayrıntılı ve ilgi çekici eğitim ortamı oluşturur, destekler ve bunun sürdürülmesini sağlar.

Profesyonel Uygulamada Mükemmellik. Eğitim yöneticileri, kurumlarındaki profesyonel öğrenme ve yeniliğe dayalı ortamları desteklemek suretiyle eğitimcileri güçlendirerek teknoloji ve kaynakların bütünleştirilmesi yoluyla öğrencilerin öğrenmesini geliştirir.

Sistematik Gelişim. Eğitim yöneticileri, örgütün sürekli gelişimi için bilgi ve teknoloji kaynaklarını en etkili ve verimli kullanılması için dijital çağ liderliğini ve yönetimini sağlar.

Dijital Vatandaşlık. Eğitim yöneticileri, sosyal, etik, yasal konu ve sorumluluklara ilişkin bir anlayış tasarlar ve geliştirir böylelikle dijital kültürün daha iyi gelişimini desteklemek konusunda tüm imkanları seferber eder.

Anderson \& Dexter (2005)'e göre, eğitim-öğretim süreçlerinde yaşanan değişimler beraberinde okul yöneticilerine yeni roller eklemiş olup bunlardan biri de gelişen çă̆ın 
vazgeçilmezi olan teknoloji liderliği rolüdür. Sincar (2009), araştırmasında teknoloji lideri olarak okul yöneticilerinin sahip olması gereken rolleri; insan merkezlilik, vizyon, iletişim ve işbirliği ve destek başlıkları altında toplamıştır. Teknoloji lideri olarak okul yöneticisi teknolojik değişimlerin eğitime etkisini iyi bilmelidir. Ayrıca mevcut teknolojilerden etkili biçimde yararlanabilmek hususunda da okul yöneticilerine büyük iş düşmektedir. Teknolojiyi anlama, tanıma, teknolojik uygulamaları bilme ve hızlı değişen süreci de benimseyebilme, okul yöneticilerinin günümüzde yapması gereken sıradan işler haline gelmektedir. Günümüzde iyi bir eğitim lideri olmak okul yöneticileri için tek başına yeterli görülmediği düşünülmektedir (Aydoğan \& Helvac1, 2010; Sezer \& Deryakulu, 2012).

Teknolojinin gelişmesiyle birlikte eğitim ile teknolojiyi buluşturan birçok proje (FATİH, EBA, e-Okul, Kodlama Öğreniyorum vb.) okullarda uygulanmaktadır. Okul yöneticilerine düşen önemli görevlerden biri de MEB'in yürüttüğü bu projelerin okullarda etkin bir şekilde hayata geçirilmesini sağlamaktır. Okulda teknoloji kullanımı ve teknolojinin geliştirilmesi konusunda okul yöneticilerinin rol üstlenmeleri kaçınılmazdır. Bilgi çağının okulunu yönetecek olan okul yöneticilerinin teknolojik yeterlikleri önem arz etmektedir. Ergişi (2005)'e göre, okul yöneticilerinin bu konuda yeterlik kazanmaları, öncelikle okulda teknoloji kullanımına önem vererek, bu konuda çaba göstermeleri gerektiği belirtilmektedir. Teknolojik ürünlerin eğitim ortamında kullanılması demek, teknolojideki ilerlemeler sonucu ortaya çıkan her aracı, eğitim ortamlarında rastgele kullanmak demek değildir. Eğitimöğretimi daha nitelikli hale getirmek için teknolojik gelişmeler sonucu ortaya çıan araçgereçlerin okul, sınıf ve öğrenme sürecinde belirli bir plan dâhilinde ve aktif biçimde kullanılması gerekmektedir (Şişman-Eren, 2010). Kısaca, teknoloji lideri olarak okul yöneticisi, teknolojik değişimlerin eğitime olan muhtemel etkilerini iyi analiz etmeli, bu analizler sonucunda gerekli çıkarımları yaparak yönettiği kurumu sürekli eğitimden geçirmelidir. Böylelikle örgüt yeniliklere uyum sağlayan ve yaşanabilecek değişikliklere her zaman hazırlıklı bir halde tutulmalıdır.

\section{Okullarda Ĕ̆itim Öğretim İşleri:}

Okullarda gerçekleşen faaliyetler genel olarak eğitim işleri ve öğretim işleri olmak üzere iki ana başlıkta incelenebilir. Okul yöneticileri hem öğretim işlerini hem de eğitim işlerini planlamak ve eş zamanlı olarak eğitim ve öğretimin birbirini destekleyici biçimde sürdürülmesini sağlamak durumundadır (Çalık \& Şirin, 2007; Aypay, Balıkçı \& Şahin, 2013). Bir okulda eğitimin kaliteli ve sürdürülebilir olması için bu işlerin birbiriyle uyum içinde ve 
eksiksiz biçimde yürümesi gerektiği söylenebilir. Aksoy (2012), okullarda gerçekleştirilen eğitim ve öğretim işlerini Tablo 1.' de verilen başlıklar altında toplamıştır:

Tablo 1. Eğitim İşleri ve Öğretim İşleri

\begin{tabular}{|c|c|}
\hline EĞİTIM İŞLERİ & ÖĞRETİM İŞLERİ \\
\hline $\begin{array}{l}\text { - Rehberlik ve psikolojik danışma hizmetleri, } \\
\text { - } \quad \text { Öğrenci disiplin işleri, } \\
\text { - } \quad \text { Toplantılar, } \\
\text { - } \quad \text { Okesleki çalışmalar, } \\
\text { - } \quad \text { Satın alma komişönononu, } \\
\text { - Okuldaki sosyal etkinlikler, } \\
\text { - Okul-çevre ilişkileri, } \\
\text { - Okul ve aile işbirliği, } \\
\text { - Nöbet işleri }\end{array}$ & 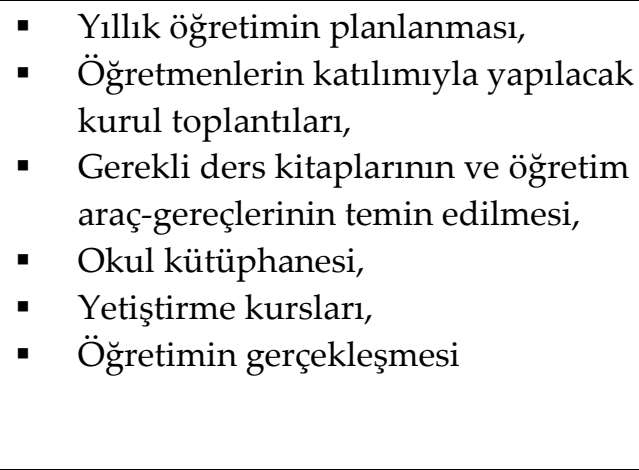 \\
\hline
\end{tabular}

Etkili bir eğitim öğretim ortamının gerçekleşmesi için başarılı bir okul müdürü ve bunun yanı sıra fiziksel ortamın ve personel sayısının yeterliliği, sınıf ortamında gerekli donanımların varlığı gibi etmenlerin de rolü vardır. Fakat tüm bunların yetersiz olduğu okullarda da başarı örnekleri mevcuttur. Bu başarıda, öğrencilerin özel gayretleri ve öğretmenlerin özverileri çok önemlidir. Ancak, okulun diğer çalışanlarının bu çabasını tetikleyen en önemli faktör; lider konumunda olan okul müdürünün gayreti ve özverisidir. Dolayısıyla her başarılı okulda en büyük pay sahibinin okul müdürü olduğu belirtilmektedir (Gürbüz, Erdem \& Yıldırım, 2013). Üzerindeki görev ve sorumlulukları diğer paydaşlarıyla işbirliği halinde yürütebilen okul müdürü, etkili ve verimli bir eğitim ortamı sağlayarak tüm paydaşların eşgüdüm halinde çalışmasına da öncülük eder.

$\mathrm{Bu}$ araştırmanın amacı okul yöneticilerinin teknoloji liderliği özyeterliklerini ve eğitim öğretim işlerini gerçekleştirme düzeylerine ilişkin algılarını tespit etmek ve bu değişkenlerin birbirleriyle olan ilişkilerini incelemektir. Bu görevler çerçevesinde aşağıdaki sorulara bu çalışmada cevap aranmaktadır:

1- Okul yöneticilerinin teknoloji liderliği özyeterlikleri ve eğitim öğretim işleri gerçekleştirme düzeyleri ne durumdadır?

2- Okul yöneticilerinin teknoloji liderliği özyeterlikleri ve eğitim öğretim işleri gerçekleştirme düzeyleri; a) görev yaptıkları okul türüne, b) ilçe veya il merkezinde çalışma durumuna, c) cinsiyete, d) yaşa, e) eğitim durumuna ve f) bilişim teknolojileri ile ilgili hizmet içi eğitim alıp almadıklarına göre farklılaşmakta mıdır? 
3- Okul yöneticilerinin teknoloji liderliği özyeterlikleri ile eğitim öğretim işlerini gerçekleştirme düzeyleri arasında anlamlı ilişki var mıdır?

4- Okul yöneticilerinin eğitim öğretim işlerini gerçekleştirme düzeyleri teknoloji liderliği yeterliklerini anlamlı bir şekilde yordamakta mıdır?

\section{Yöntem}

\section{Araştırma Modeli}

Bu çalışmada nicel araştırma yöntemi kullanılmıştır. Araştırma, betimsel bir çalışma olup, veriler tarama modeli ile toplanmıştır. Tarama modeli, şuan halen var olan ya da geçmişte olmuş bir durumu var olduğu şekliyle betimlemeyi hedefleyen araştırmalar için uygun bir modeldir (Karasar, 2008). Araştırmanın konusu olan birey, nesne ya da olay kendi koşulları içinde ve olduğu gibi tanımlanmaya çalışılacağı zaman betimsel yöntem kullanılır (Büyüköztürk, Çakmak, Akgün, Karadeniz \& Demirel, 2010).

\section{Evren ve Örneklem}

Okul yöneticileri, Tokat ili merkez ve tüm ilçelerinde MEB'e bağlı ilk ve ortaöğretim kurumlarında görev yapmakta olan müdür ve müdür yardımcılarıdır. Okul yöneticileri evreninde 309 müdür, 525 müdür yardımcısı ve 33 başmüdür yardımcısı olmak üzere toplam 867 yönetici mevcuttur. İl Milli Eğitim Müdürlüğünden resmî izin alındıktan sonra herhangi bir örnekleme yöntemine gidilmeksizin çalışma evrenindeki tüm yöneticilere veri toplama formu ulaştırılmıştır. Uygulama gönüllülük esasına dayalı olarak yapılmış ve toplam 140 kişi katılmıştır. Araştırma, veri toplama formuna eksiksiz geri dönüş yapan 112 yöneticinin verileri üzerinden analiz edilmiştir. Aşağıda evrene ulaşma oranı ve kullanılabilir veri dönüş oranları hesaplanmıştır. Tablo 2.'de ise çalışmaya katılan okul yöneticilerinin çeşitli değişkenler bakımından özellikleri sunulmaktadır.

Kullanılabilir veri dönüş oranı: 112/140 = 0,80

Evrene ulaşma oranı: $140 / 867=0,16$ 
Tablo 2. Okul yöneticileri örnekleminin genel özellikleri

\begin{tabular}{|c|c|c|c|}
\hline Değişkenler & & $f$ & $\%$ \\
\hline \multirow{5}{*}{ Görev Yaptıkları Okul Türü } & İlkokul & 37 & 33,04 \\
\hline & Ortaokul & 37 & 33,04 \\
\hline & Genel Lise & 10 & 8,93 \\
\hline & Meslek Lisesi & 25 & 22,32 \\
\hline & Yaygın Eğitim & 3 & 2,68 \\
\hline \multirow{2}{*}{ Cinsiyet } & Kadın & 12 & 10,71 \\
\hline & Erkek & 100 & 89,29 \\
\hline \multirow{3}{*}{ Yaş } & $20-34$ & 21 & 18,75 \\
\hline & $35-49$ & 64 & 57,14 \\
\hline & $50-64$ & 27 & 24,11 \\
\hline \multirow{2}{*}{ Görev yaptıkları Yer } & İl & 66 & 58,93 \\
\hline & İlçe & 46 & 41,07 \\
\hline \multirow{3}{*}{ Eğitim Durumları } & Ön Lisans & 12 & 6,23 \\
\hline & Lisans & 89 & 85,09 \\
\hline & Yüksek Lisans & 11 & 8,67 \\
\hline Bilişim Teknolojileri Konusunda & Evet & 73 & 65,18 \\
\hline HİE Alıp Almama Durumu & Hayır & 39 & 34,82 \\
\hline
\end{tabular}

\section{Ölçme Araçları}

Araştırmada veri toplama aracı olarak, Hacıfazlığ lu, Karadeniz \& Dalgıç (2011a) tarafından ülkemize uyarlanan “Teknoloji Liderliği Özyeterlik Ölçeği” kullanılmıştır. Eğitim yöneticilerinin teknoloji konusundaki özyeterliklerini ölçmek üzere hazırlanan bu ölçek beş faktörden ve 26 maddeden oluşmaktadır. Bu faktörler; vizyoner liderlik, dijital çağ öğrenme kültürü, profesyonel uygulamada mükemmellik, sistematik gelişim ve dijital vatandaşlık şeklindedir. Ölçeğin orijinalindeki Cronbach's alfa güvenirlik değerleri genel toplamda .97 iken alt boyutlarda ise .83 ile .92 arasında değişmektedir. Bu çalışmadaki Cronbach's alfa güvenirlik değerleri ise; genel toplamda .98 iken alt boyutlarda ise .89 ile .94 arasında değişmektedir.

Araştırmada kullanılan bir diğer ölçme aracı da Aksoy (2012) tarafından geliştirilen “Eğitim-Öğretim İşleri Ölçeği”dir. Ölçek toplam 55 madde ve altı faktörden oluşmaktadır. Bu faktörler; politikalar ve sosyal etkinlikler, öğretimin geliştirilmesine yönelik destekleyici hizmetler, eğitim-öğretimin geliştirilmesine yönelik yönetim görevleri, rehberlik hizmetleri, etkililik ve düzenlilik ile gelişim ve değerlendirme şeklindedir. Ölçeğin orijinalindeki Cronbach's alfa güvenirlik değerleri genel toplamda .98 iken alt boyutlarda ise .84 ile .97 arasında değişmektedir. Ölçeğin bu çalışmadaki Cronbach's alfa güvenirlik değerleri ise; genel toplamda .98 iken alt boyutlarda ise .83 ile .96 arasında değişmektedir. Bu bilgilerden yola çıkarak kullanılan ölçme araçlarının güvenirliğinin yüksek olduğu söylenebilir. 


\section{Veri Toplama Süreci ve Analizi}

Araştırma kapsamında ölçme araçlarının kullanımına yönelik gerekli izinler e-posta yoluyla alınmıştır. Veri toplama süreci 2014 Ocak ayında gerekli izinlerin İl Milli Eğitim Müdürlüğü'nden alınmasıyla başlamış olup yaklaşık 3 ay sürmüştür. Araştırma için gerekli verilerin toplanacağ formlar Tokat il ve ilçelerindeki tüm okullara Acil Duyuru ve İletişim Sistemi (ADİS) üzerinden ulaştırılmıştır. ADİS sistemi, Tokat ili Milli Eğitim Müdürlüğü ve okullar arasında elektronik ortamda haberleşme amacıyla geliştirilmiş ve hali hazırda kullanılmakta olan bir ortamdır. Bu şekilde elde edilen verilere ek olarak, Tokat merkezdeki tüm okullara da yüz yüze ulaşılmış, gönüllülük çerçevesinde araştırmaya katılmak isteyen yöneticilere de basılı ölçek formu ayrıca bırakılmıştır. Gönüllülük esasına uygun olarak gerek çevrimiçi gerekse basılı biçimde elden toplanan 140 veri toplama formundan, eksik veri içerenler elenmiştir. Kalan 112 formun verileri üzerinden araştırmaya ilişkin analizler SPSS 17.0 yazılımı ile yapılmıştır. Yapılan tüm analizlerde 05 anlamlılık düzeyi kullanılmıştır. Verilerin analizinde frekans, yüzde, ortalama ve standart sapmalardan yararlanılmıştır. Bağımsız değişken kategori sayısına göre parametrik testlerin önkoşullarının sağlandığı durumlar için bağımsız gruplar t-testi veya ANOVA kullanılırken, ön koşulların sağlanmadığı durumlarda Mann Whitney U ve Kruskal Wallis testleri kullanılmıştır. Üçüncü alt problemin analizinde korelasyon testinden yararlanılırken, dördüncü alt problem için de regresyon analizi uygulanmıştır.

\section{Bulgular}

$\mathrm{Bu}$ bölümde araştırma sorularına ilişkin elde edilen bulgular sunulmuştur. $\mathrm{Bu}$ bulgulara ulaşmak için iki farklı veri toplama aracından toplanan veriler incelenmiştir. İlk aşamada okul yöneticilerinin teknoloji liderliği özyeterliklerine ilişkin kendi algıları tespit edilmeye çalışılmıştır. İkinci aşamada ise, okul yöneticilerinin okullardaki eğitim öğretim işlerini gerçekleştirme düzeyleri tespit edilmeye çalışılmıştır. Ardından bu iki değişkenin birbirleriyle olan ilişkileri incelenmiştir. Bu çerçevede araştırma alt problemlerine yanıt verecek biçimde düzenlenen bulgular aşağıda sunulmuştur.

\section{Okul Yöneticilerinin Teknoloji Liderliği Özyeterliklerine İlişkin Bulgular}

Okul yöneticilerinin teknoloji liderliği özyeterliklerinin ne düzeyde olduğunu belirlemek için ortalama ve standart sapma değerleri hesaplanmış, sonuçlar Tablo 3.'de verilmiştir. 
Tablo 3. Okul Yöneticilerinin Teknoloji Liderliği Özyeterlik Algıları

\begin{tabular}{|c|c|c|c|c|}
\hline \multirow[t]{2}{*}{ Faktör } & \multicolumn{2}{|c|}{$\begin{array}{c}\text { Yönetici } \\
\text { (ortalama puan) }\end{array}$} & \multicolumn{2}{|c|}{$\begin{array}{c}\text { Yönetici } \\
\text { (5 üzerinden ortalama puan) }\end{array}$} \\
\hline & $\bar{X}$ & ss & $\bar{X}$ & ss \\
\hline Vizyoner liderlik & 11.62 & 2.62 & 2.91 & 0.65 \\
\hline Dijital çağ öğrenme kültürü & 19.12 & 4.34 & 3.90 & 0.72 \\
\hline Profesyonel uygulamada mükemmellik & 15.71 & 3.17 & 3.14 & 0.63 \\
\hline Sistematik gelişim & 19.45 & 3.85 & 3.24 & 0.64 \\
\hline Dijital vatandaşlık & 15.55 & 3.58 & 3.11 & 0.72 \\
\hline Genel toplam & 81.46 & 15.29 & 3.13 & 0.59 \\
\hline
\end{tabular}

Okul yöneticilerinin teknoloji liderliğine ilişkin özyeterlik algıları genel toplamının $(\bar{X}=3.13$; ss = .59) “orta düzeyde katılıyorum” aralığında olduğu Tablo 3.'de görülmektedir. Alt boyutlara verilen cevaplar incelendiğinde ise yönetici puanlarının 2.91 - 3.90 aralığında değiştiği bulgusuna ulaşılmıştır. "Vizyoner liderlik" alt boyutundaki yönetici puanları $(\bar{X}=2.91$; ss = .65) “orta düzeyde katılıyorum” aralığındadır. “Dijital çağ öğrenme kültürü" alt boyutuna verilen yanıtlar $(\bar{X}=3.90 ; \quad$ ss $=.72)$ ise "yeterli düzeyde" bulunmuştur. Bir diğer alt boyut olan "Profesyonel uygulamada mükemmellik" alt boyutuna ilişkin yönetici cevapları $(\bar{X}=3.14$; ss $=.63)$ yine "orta düzeyde katılıyorum" aralığında yer almaktadır. "Sistematik gelişim" alt boyutundaki maddelere yöneticilerin verdiği yanıtlar $(\bar{X}=3.24$; ss $=$ .64) "orta düzeyde katılıyorum" aralığında yer almıştır. Son olarak “Dijital vatandaşlık" alt boyutuna verilen yönetici cevapları da $(\bar{X}=3.11$; ss $=.72)$ "orta düzeyde kat1liyorum" aralığında yer almıştır. Alt boyutlara verilen cevaplar incelendiğinde en yüksek algı puanına sahip olan alt boyutun "dijital vatandaşlık" olduğu bulgusuna ulaşılmıştır. Yöneticilerin en düşük alg1 puanları ile cevaplandırdığı alt boyut ise "vizyoner liderlik" olduğu bulgusuna ulaşılmıştır.

Okul yöneticilerinin teknoloji liderliği özyeterlik algıları genel toplamının çalıştıkları okul türüne göre anlamlı fark gösterip göstermediği Kruskal Wallis $\mathrm{H}$ testi ile incelenmiş ve anlamlı farklılaşma olduğu görülmüştür $\left(X^{2}(4)=13,992 ; \mathrm{p}<.05\right)$. Meslek lisesinde çalışan okul yöneticilerinin $(\bar{X}=87.48$; ss $=17.57)$ teknoloji liderliği özyeterlik algıları genel toplamı ilkokulda görevli yöneticilerden $(\bar{X}=75.54$; ss $=14.69)$ daha yüksektir $\left(X^{2}(4)=13.992 ; \mathrm{p}<\right.$ $.05)$.

Okul yöneticilerinin teknoloji liderliği özyeterlik algıları, ilçe veya il merkezinde çalışma durumlarına göre t-testi analizi ile karşılaştırılmıştır. Teknoloji liderliği özyeterlik algısı genel 
toplamı da ilçede çalışan yöneticilerde $(\bar{X}=84.98$; ss $=15.37)$ il merkezinde çalışanlara $(\bar{X}=$ 79.02; ss $=14.87)$ göre istatistiksel olarak anlamlı ve daha yüksektir. $\left(\mathrm{t}_{(110)}=2.060 ; \mathrm{p}<.05\right)$.

Okul yöneticilerinin teknoloji liderliği özyeterlik algılarının cinsiyete göre farklılaşıp farklılaşmadığını test etmek için Mann Whitney U analizi kullanılmıştır. Teknoloji liderliği özyeterlik algısı genel toplamı alt boyutunda erkek yöneticilerin $(\bar{X}=81.10$; ss $=14.91)$ algıları ile kadın yöneticilerin $(\bar{X}=84.50$; ss $=18.68)$ algıları arasında istatistiksel olarak anlamlı bir fark olmadığı görülmektedir $(U=480.50 ; p>~ .05)$. Okul yöneticilerinin teknoloji liderliği özyeterlik algıları genel toplamının yaşa göre anlamlı fark gösterip göstermediği Kruskal Wallis H testi ile incelenmiş ve anlamlı farklılaşma olmadığı görülmüştür $\left(X^{2}(2)=\right.$ 2.438; p>.05). Okul yöneticilerinin teknoloji liderliği özyeterlik algılarının eğitim durumlarına göre farklılaşıp farklılaşmadığını test etmek için Kruskal Wallis H testinden yararlanılmış ve eğitim durumlarına göre istatistiksel olarak anlamlı bir farklılaşma görülmemiştir $\left(X^{2}(2)=\right.$ 2.267; $\quad \mathrm{p}>$.05). Okul yöneticilerinin teknoloji liderliği özyeterlik algılarının, bilişim teknolojileri ile ilgili hizmet içi eğitim alma durumlarına göre t-testi analizi ile karşılaştırılmıştır. Hizmet içi eğitim (H.İ.E) alan okul yöneticilerinin $(\bar{X}=81.82$; ss $=14.19)$ teknoloji liderliği özyeterlik algıları genel toplamının, H.İ.E almayan okul yöneticilerinden $(\bar{X}=80.79$; ss $=$ 17.35) anlamlı olarak farklılaşmadığı görülmektedir $\left(t_{(110)}=0.337 ; p>.05\right)$.

\section{Okul Yöneticilerinin Eğitim Öğretim İşlerini Gerçekleştirme Düzeylerine İlişkin}

\section{Bulgular}

Okul yöneticilerinin eğitim öğretim işlerini gerçekleştirme düzeylerinin ne seviyede olduğunu belirlemek için ortalama ve standart sapma değerleri hesaplanmış, sonuçlar Tablo 4'de verilmiştir.

Tablo 4. Okul Yöneticilerinin Eğitim Öğretim İşlerini Gerçekleştirme Düzeylerine İlişkin Algiları

\begin{tabular}{lcc}
\hline \multirow{2}{*}{ Faktör } & \multicolumn{2}{c}{ Yönetici (N=112) } \\
\cline { 2 - 3 } & $\bar{X}$ & ss \\
\hline Politikalar ve sosyal etkinlikler & 3.94 & 0.58 \\
Öğretimin geliştirilmesine yönelik destekleyici hizmetler & 4.00 & 0.74 \\
Eğitim-öğretimin geliştirilmesine yönelik yönetim görevleri & 3.99 & 0.68 \\
Rehberlik hizmetleri & 3.71 & 0.92 \\
Etkililik ve Düzenlilik & 3.75 & 0.88 \\
Gelişim ve değerlendirme & 4.00 & 0.77 \\
\hline Genel toplam & 3.95 & 0.63 \\
\hline
\end{tabular}


Eğitim öğretim işleri gerçekleştirme düzeyleri genel toplamına bakıldığında yönetici algılarının ( $\bar{X}=3.95 ;$ ss $=0.63)$ “çok katılıyorum" düzeyinde olduğu görülmektedir. "Politikalar ve sosyal etkinlikler" alt boyutuna yöneticilerin verdiği yanıtlar ( $\bar{X}=3.94 ;$ ss $=0.58)$ incelendiğinde bu faktördeki maddelere ilişkin yönetici algılarının "çok katılıyorum" düzeyinde olduğu görülmüştür. Bir diğer alt boyut olan “Öğretimin geliştirilmesine yönelik destekleyici hizmetler" başlığı altındaki sorulara verilen yönetici yanıtlarının ( $\bar{X}=4.00$; ss = 0.74) “çok katılıyorum" düzeyinde olduğu görülmüştür. "EğitimÖğretimin Geliştirilmesine Yönelik Yönetim Görevleri” alt boyutunda ise yöneticiler yine $(\bar{X}=3.99 ;$ ss = .68) "çok katılıyorum" düzeyinde yanıtlar vermiştir. Yöneticilerin "Rehberlik Hizmetleri" alt boyutuna ilişkin algılarının $(\bar{X}=3.71$; ss $=.92)$ ise yine "çok katılıyorum" düzeyinde olduğu bulgusuna ulaşılmıştır. “Etkililik ve Düzenlilik” alt boyutunda yer alan sorulara ilişkin yönetici algıları $(\bar{X}=3.75$; ss $=.88$ ) diğer alt boyutlarla benzer şekilde "çok katılıyorum düzeyinde" yer almıştır. "Gelişim ve Değerlendirme" başlığında yer alan maddelerde de yönetici algılarının ( $\bar{X}=4.00$; ss $=.77)$ "çok katıllyorum" düzeyinde olduğu bulgusu elde edilmiştir.

Okul yöneticilerinin eğitim öğretim işlerini gerçekleştirme düzeylerinin çalıştıkları okul türüne göre anlamlı fark gösterip göstermediği Kruskal Wallis $\mathrm{H}$ testi ile incelenmiş ve görev yapılan okul türüne göre istatistiksel olarak anlamlı bir şekilde farklılaşmadığı görülmüştür. Alt boyutlar açısından incelendiğinde; Etkililik ve Düzenlilik alt boyutunda eğitim öğretim işlerini gerçekleştirme düzeyleri ile okul türü arasında anlamlı bir fark olduğu görülmektedir $\left(X^{2}(4)=11.313 ; \mathrm{p}<.05\right)$. Tukey Post Hoc analizi Meslek lisesinde çalışan okul yöneticilerinin $(\bar{X}=4.07$; ss $=0.87)$, etkililik ve düzenlilik alt boyutuna ilişkin algılarının ilkokulda çalışan yöneticilere göre $(\bar{X}=3.41$; ss $=0.84)$ daha yüksek olduğunu göstermektedir.

Okul yöneticilerinin eğitim öğretim işlerini gerçekleştirme düzeyleri, ilçe veya il merkezinde çalışma durumlarına göre t-testi analizi ile karşılaştırılmıştır. Eğitim öğretim işleri gerçekleştirme düzeyleri toplamı puanları il merkezinde çalışan yöneticiler ile ilçede çalışan yöneticiler arasında anlamlı bir farklılık göstermemektedir $\left(t_{(75.415)}=0.230 ; p>.05\right)$. Okul yöneticilerinin eğitim öğretim işlerini gerçekleştirme düzeylerinin cinsiyete göre farklılaşıp farklılaşmadığını test etmek için Mann Whitney U analizi kullanılmıştır. Analiz sonuçları incelendiğinde; eğitim öğretim işleri gerçekleştirme düzeyleri toplamında erkek okul 
yöneticileri ( $\bar{X}=3.95$; ss $=0.63$ ) ile kadın yöneticiler $(\bar{X}=3.93$; ss $=0.70)$ arasında istatistiksel olarak anlamlı fark bulunmamıştır $(\mathrm{U}=548.00 ; \mathrm{p}>$.05).

Okul yöneticilerinin eğitim öğretim işlerini gerçekleştirme düzeyleri toplamının yaşa göre anlamlı fark gösterip göstermediği Kruskal Wallis $\mathrm{H}$ testi ile incelenmiş ve anlamlı farklılaşma olmadığı görülmüştür $\left(X^{2}(2)=5.776\right.$; p> .05). “Öğretimin geliştirilmesine yönelik destekleyici hizmetler" alt boyutunda 20-34 yaş grubundaki yöneticilerin $(\bar{X}=3.57$; ss $=0.84$ ) algıları, 35-49 yaş grubundaki ( $\bar{X}=4.10$; ss $=0.74$ ) yöneticilerden ve $50-64$ yaş grubundaki ( $\bar{X}=4.11$; ss $=0.53)$ yöneticilerden daha düşüktür. Aradaki bu fark istatistiksel olarak anlamlıdır $\left(X^{2}(2)=7.647 ; \mathrm{p}<.05\right)$. Rehberlik alt boyutu incelendiğinde de benzer şekilde 2034 yaş grubundaki yöneticilerin ( $\bar{X}=3.14$; ss $=1.06)$ Eğitim öğretim işleri gerçekleştirme düzeyleri toplamı $35-49$ yaş grubundaki $(\bar{X}=3.92$; ss $=0.87)$ yöneticilerden ve $50-64$ yaş grubundaki $(\bar{X}=3.78 ;$ ss $=0,74)$ yöneticilerden anlamlı olarak daha düşüktür $\left(X^{2}(2)=\right.$ 9.357; $\mathrm{p}<.05)$.

Okul yöneticilerinin eğitim öğretim işlerini gerçekleştirme düzeylerinin eğitim durumlarına göre fark gösterip göstermediği Kruskal Wallis $\mathrm{H}$ testi analizi ile incelenmiş ve okul yöneticilerinin eğitim öğretim işlerini gerçekleştirme düzeyleri ile eğitim durumları arasında istatistiksel olarak anlamlı bir fark olmadığı görülmüş̧ür $\left(X^{2}(2)=1.316\right.$; $\left.p>.05\right)$. Okul yöneticilerinin, eğitim öğretim işlerini gerçekleştirme düzeylerinin hizmet içi eğitim alıp almama durumlarına göre farklılaşıp farklılaşmadığı t-testi analizi ile karşılaştırılmış, ve hizmetiçi eğitim (HİE) alan okul yöneticileri $(\bar{X}=3.99$; ss $=.57)$ ile HíE almayan okul yöneticileri

$(\bar{X}=3.88 ; \mathrm{ss}=.75)$ arasında anlamlı bir fark görülmemiştir $\left(\mathrm{t}_{(109)}=\right.$ $.847 ; \mathrm{p}>.05)$.

\section{Okul Yöneticilerinin Teknoloji Liderliği Özyeterlikleri İle Eğitim Öğretim İşlerini}

\section{Gerçekleştirme Düzeyleri Arasında İlişkiye Yönelik Bulgular}

Okul yöneticilerinin teknoloji liderliği özyeterlikleri ile eğitim öğretim işlerini gerçekleştirme düzeylerine ilişkin algıları arasındaki ilişkinin analizi için Pearson momentler çarpımı korelasyon katsayısından yararlanılmıştır. Makalenin ekinde yer alan tablo (Bkz. EK 1.) incelendiğinde, yöneticilerin eğitim öğretim işlerini gerçekleştirme düzeylerine ilişkin algıları toplamı ile teknoloji liderliği özyeterlik algıları alt boyutları arasında; Vizyoner liderlik $(r=.41, \mathrm{p}<.01)$, Dijital çağ öğrenme kültürü $(r=.51, \mathrm{p}<.01)$, Profesyonel uygulamada mükemmellik $(r=.47, \mathrm{p}<.01)$,Sistematik gelişim $(r=.45, \mathrm{p}<.01)$, Dijital vatandaşl1k $(r=.51$, 
$\mathrm{p}<$.01) pozitif yönde, orta düzeyde ve anlamlı bir ilişki olduğu görülmektedir. Öte taraftan, teknoloji liderliği yeterlik algıları toplamı ile eğitim öğretim işleri gerçekleştirme düzeyleri ölçeğinin alt boyutları arasında da benzer şekilde; Politikalar ve Sosyal etkinlikler $(r=.51$, p< .01), Öğretimin Geliştirilmesine Yönelik Destekleyici Hizmetler $(r=.47, \mathrm{p}<.01)$, EğitimÖğretimin Geliştirilmesine Yönelik Yönetim Görevleri ( $r=.55, \mathrm{p}<.01)$, Rehberlik Hizmetleri $(r=.40, \mathrm{p}<.01)$, Etkililik ve Düzenlilik $(r=.45, \mathrm{p}<.01)$, Gelişim ve değerlendirme $(r=.51, \mathrm{p}<$ .01), pozitif yönde, orta düzeyde ve anlamlı bir ilişki olduğu görülmektedir. Eğitim öğretim işleri gerçekleştirme düzeylerine ilişkin algıları toplamı ile teknoloji liderliği özyeterlik algıları toplamı arasında $(r=.55, \mathrm{p}<.01)$ pozitif yönde, orta düzeyde ve anlamlı bir ilişki görülmektedir.

Okul Yöneticilerinin Teknoloji Liderliği Yeterliklerinin Ĕgitim Öğretim İşlerini Gerçekleştirme Düzeylerini Yordamasına İlişkin Bulgular

Okul yöneticilerinin eğitim öğretim işlerini gerçekleştirme düzeylerinin, teknoloji liderliği özyeterlikleri tarafından yordanıp yordanmadığını test etmek için basit regresyon analizi yapılmıştır. Analiz sonuçları Tablo 5'de verilmiş olup, regresyon modeli istatistiksel olarak anlamlıdır $\left(\mathrm{F}_{(1,109)}=46.526, p=.000\right)$. Yani eğitim öğretim işleri gerçekleştirme düzeylerine ilişkin varyansın \%29,3'ünün okul yöneticilerinin teknoloji liderliği özyeterlik düzeyleri ile açıklandığı ifade edilebilir.

Tablo 5. Okul Yöneticilerinin Eğitim Öğretim İşlerini Gerçekleştirme Düzeylerinin Teknoloji Liderliği Özyeterlikleri Tarafından Yordanması

\begin{tabular}{|c|c|c|c|c|c|c|c|}
\hline \multirow{2}{*}{ Değişkenler } & \multicolumn{3}{|c|}{ Standart } & \multirow[b]{2}{*}{$t$} & \multirow[b]{2}{*}{$p$} & \multirow[b]{2}{*}{ İkili $r$} & \multirow{2}{*}{$\begin{array}{c}\text { Kismi } \\
r\end{array}$} \\
\hline & B & hata & $\beta$ & & & & \\
\hline \multicolumn{8}{|l|}{$\begin{array}{l}\text { Teknoloji Liderliği } \\
\text { Özyeterlik Ölçeği (TELÖY) }\end{array}$} \\
\hline Sabit & 2.109 & 0.275 & & 7.676 & .000 & & \\
\hline TELÖY & 0.023 & 0.003 & .547 & 6.821 & .000 & .547 & .547 \\
\hline Adj. $R^{2}=, 293$ & $F_{(1,109)}=46,526$ & $p=, 000$ & & & & & \\
\hline
\end{tabular}

\section{Sonuç ve Tartışma}

Yapılan araştırmanın sonucunda elde edilen bulgular incelendiğinde okul yöneticilerinin teknoloji liderliği özyeterlik algılarının sadece dijital çağ öğrenme kültürü boyutunda "yeterli düzeyde", diğer alt boyutlarda ve genel toplamda ise "orta düzeyde" olduğu görülmüştür. Dijital çağ öğrenme kültürü boyutunun diğerlerinden daha yüksek olması, okulda yenilikleri ve yeni teknolojileri destekleyen öğrenme-öğretme etkinliklerine açık bir iklimin oluşturulması açısından önemlidir. Bu boyutta yüksek yeterliğe sahip okul 
yöneticileri, okullarında teknolojinin öğrenme-öğretme etkinlikleri için sıklıkla ve etkili olarak kullanımını teşvik ederken, öğrencilerin bireysel ihtiyaçlarını karşılayan teknoloji donanımlı öğrenme ortamları ve öğrenme kaynakları da bulmaya çalıştıkları belirtilmektedir (Bülbül \& Çuhadar, 2012). Ortaya çıkan bu sonuca dayanarak okul yöneticilerinin teknoloji liderliği özyeterlik algılarının yüksek olduğu söylenebilir. Hayytov (2013)'un çalışmasında da okul yöneticilerinin 'önemli oranda' teknoloji liderliği yeterlik algılarına sahip oldukları; Ada, Görgülü \& Küçükali (2013) tarafından yapılan araştırmada 'çoğu zaman' teknolojik liderlik yeterliklerini gösterdikleri belirtilmiştir. Alanyazında benzer bulgulara başka çalışmalarda da rastlanmaktadır (Anderson \& Dexter, 2005; Can, 2008; Şişman-Eren, 2010; Baş, 2012; Bülbül \& Çuhadar, 2012; Sezer \& Deryakulu, 2012). Memişoğlu \& Özsarıkamış (2009) tarafından gerçekleştirilen çalışmada da ilköğretim okulu yöneticilerinin, kendilerini bilgi yönetimi yeterlikleri konusunda "üst düzeyde yeterli" olarak değerlendirdikleri görülmüştür.

Yapılan araştırmanın sonucunda elde edilen bilgilere göre, meslek lisesinde görev yapan okul yöneticilerinin teknoloji liderliği özyeterlik algıları, ilkokulda görev yapan yöneticilerden anlamlı olarak daha yüksek bulunmuştur. Bu okulların yapıları ve misyonları gereği elektronik/dijital ortam ve kaynakların okul süreçlerine entegrasyonu, bu kaynakların öğrenci ve öğretmenler tarafından da etkili kullanımı ve uygulanan proje pazarı gibi etkinliklerle kurumlarını öne çıkarmak için dijital kültürü ve gelişimini destekleyici yaklaşımlar boyutunda araştırmaya katılan diğer okul türlerine göre daha yüksek olabileceği düşünülmektedir. Nitekim teknoloji liderliği özyeterlik algıları ile okul türü arasında anlamlı farklılık bulunmayışı da (Can, 2003; Can, 2008; Hacıfazlıŏlu, 2011; Ağaoğlu, Altınkurt, Y1lmaz \& Karaköse, 2012; Bülbül \& Çuhadar, 2012; Ada, Görgülü \& Küçükali, 2013; Hayytov, 2013) literatürde de benzer şekilde elde edilen bir diğer bulgudur.

İlçelerde çalışan yöneticilerin teknoloji liderliği konusunda kendilerini daha yeterli bulmaları dikkat çekicidir. İl merkezinde çalışan yöneticilerin teknoloji liderliği konusunda kendilerini ilçedekilere oranla daha yetersiz bulmaları gözlemledikleri farklı uygulamalar ve yönetici özyeterliklerine ilişkin yüksek beklentilerin bir sonucu olarak yorumlanabilir.

Okul yöneticilerinin cinsiyetlerine göre teknoloji liderliği özyeterlik algıları incelendiğinde anlamlı farklılıklar bulunmamıştır. Bu durum erkek ve kadın yöneticilerin teknoloji liderliği konusunda kendilerini değerlendirirken cinsiyetin belirleyici bir etkisinin olmadığı şeklinde yorumlanabilir. Alanyazında yapılan çalışmalarda da benzer sonuçlar 
elde edilmiştir (Bülbül \& Çuhadar, 2012; Hayytov, 2013). Ada, Görgülü \& Küçükali (2013) tarafından hazırlanan araştırmada elde edilen okul yöneticilerinin teknoloji liderliği özyeterliklerinin cinsiyete bağlı olarak değişmediği görülmüştür.

Okul yöneticilerinin teknoloji liderliği özyeterlik algıları ile eğitim durumları arasında istatistiksel olarak anlamlı bir farklılık bulunmamaktadır (Bostancı, 2010; ŞişmanEren, 2010; Baş, 2012; Hayytov, 2013). Araştırma sonucu tespit edilen bu sonuca göre farklı eğitim durumlarına sahip yöneticiler benzer liderlik algısına sahiptir. Sezer \& Deryakulu (2012)'nin araştırmasında da ilköğretim okul yöneticilerinin teknoloji liderliği rollerinin eğitim durumlarına göre anlamlı farklılık göstermediği görülmüştür. Hizmet içi eğitim (HİE) açısından ele alındığında; HİE alan okul yöneticilerinin teknoloji liderliği özyeterlik algıları genel toplamı, HİE almayan okul yöneticilerinden yüksek olsa da, bu araştırmada istatistiksel olarak anlamlı bir şekilde farklılaşmadığı görülmektedir. Alan yazında yapılan araştırmalarda ise HïE konusunda farklı sonuçlara ulaşan araştırmalar görülmektedir. Örneğin, Bostancı'ya (2010) göre ise liderlik ve yönetim konusunda HİE alan okul yöneticilerinin hem genel teknoloji liderliği alanında, hem de alt boyutlarında anlamlı düzeyde yüksek yeterliğe sahip oldukları görülmüştür. Bülbül \& Çuhadar (2012)'ın çalışmasında da anlamlı farklılık görülmüş ancak HİE almayanların teknoloji liderliği özyeterlik algıları daha yüksek bulunmuştur. Akbaba-Altun \& Gürer'e (2008) göre okul yöneticilerinin BT sınıflarına yönelik rollerini algılama düzeyleri okul yöneticilerinin katıldıkları HİE sayılarına göre anlamlı farklılık göstermemektedir. Hayytov'un (2013) araştırması da, yöneticilerin HİE alma durumlarının, teknoloji liderliği özyeterlik algılarında anlamlı bir ilişkiye yol açmadığını göstermektedir.

Okul yöneticilerinin eğitim öğretim işlerini gerçekleştirme düzeylerine ilişkin analiz sonuçları incelendiğinde, okul yöneticilerinin araştırmanın tüm alt boyutlarında ve genel toplamda verdikleri cevapların “çok katıllyorum” düzeyinde olduğu görülmüştür. Bu durumda okul yöneticilerinin eğitim öğretim işlerini gerçekleştirme düzeylerine ilişkin algılarının yüksek olduğu görülmektedir (Aksoy, 2012).

Okul Yöneticilerinin eğitim öğretim işleri gerçekleştirme düzeyleri ile okul türleri karşılaştırıldığında “Etkililik ve Düzenlilik" alt başlı̆̆ında anlamlı olarak farklılaştığı bulgusuna ulaşılmıştır. Elde edilen bu bulguya göre meslek lisesinde görev yapan okul yöneticilerinin ilkokulda görev yapanlara göre "Etkililik ve Düzenlilik" alt başlığında daha yüksek bir algıya sahip oldukları söylenebilir. Bu durum "etkililik ve düzenlilik" alt 
faktöründeki "toplumsal hayata yönelik projeler hazırlama", "okul gelişim yönetim ekibi" ve "düzenli okul kütüphanesi" gibi konularda meslek liselerinin ilkokullara göre daha iyi düzeyde olduğu şeklinde yorumlanabilir.

Okul yöneticilerinin eğitim öğretim işlerini gerçekleştirme algıları il veya ilçede çalışma durumlarına göre farklılaşmamaktadır. Diğer bir ifade ile okul yöneticilerinin çalıştıkları yerin il ya da ilçe merkezi olması eğitim öğretim işlerini gerçekleştirme algılarını etkilememektedir.

$\mathrm{Bu}$ araştırmada elde edilen bulgular incelendiğinde; erkek ve kadın yöneticilerin eğitim öğretim işlerini gerçekleştirme düzeylerinde kendilerini değerlendirirken benzer ve olumlu bakış açıları sergiledikleri görülmüştür. Terci (2008), cinsiyet değişkenine göre yöneticilerin yeterlik algıları arasında anlamlı farkın bulunmadığı sonucuna ulaşmıştır. Almış (2010), okul yöneticilerinin bilgiyi yönetme yeterliklerine ilişkin olarak; erkek ve kadın yöneticiler arasında sırasıyla; uygun ortam oluşturma, bilgiyi elde etme/üretme, bilgiyi depolama, bilgiyi paylaşma ve bilgiyi kullanma boyutları yönünden istatistiksel olarak anlamlı farklılık bulamamıştır. Çetin-Yılmaz (2008), kadın ve erkek okul yöneticilerinin okul işletmesi ile ilgili işlerde bilgisayar teknolojisinden yararlanma düzeyleri arasında anlamlı fark bulmuşken, tüm yönetim işlerinde ise yöneticilerin bilgisayar teknolojisini kullanma yeterlikleri cinsiyete göre anlamlı olarak farklılaşmamaktadır.

Elde edilen bulgular incelendiğinde eğitim öğretim işlerini gerçekleştirme düzeyleri okul müdürlerinin yaşlarına göre anlamlı olarak farklılaşmaktadır. 20-34 yaş grubundaki okul yöneticilerinin, 35-49 yaş grubundaki ve 50-64 yaş grubundaki yöneticilere göre “Öğretimin Geliştirilmesine Yönelik Destekleyici Hizmetler" ve "Rehberlik Hizmetleri” alt boyutlarında kendilerini daha az başarılı bulmaktadırlar. $\mathrm{Bu}$ durum “Öğretimin geliştirilmesine yönelik destekleyici hizmetler "başlı̆̆ı altında yer alan "okuldaki materyallerin etkililik ve yeterliliği, okul-aile birliği uyumu, öğrenci motivasyonu, disiplin" gibi bazı başlıkların ve "rehberlik hizmetleri" alt boyutunda yer alan "Rehberlik ve psikolojik danışma hizmetleri, bilgi yarışmaları, kulüp ve toplum hizmeti çalışmaları" gibi maddelerde 20-34 yaş grubundaki yöneticilerin kendilerini yeterli bulmadıkları şeklinde yorumlanabilir. Yıldırım (2008), müdürlerin görüşlerinin yaşlarına göre anlamlı olarak farklılaştığına işaret etmektedir; 46 yaş ve üstündeki müdürlerin araç-gereç ve fiziki şartların uygunluğu alt boyunda daha iyi olduklarına ilişkin anlamlı bir fark görülmektedir. Sezer \& Deryakulu (2012)'nin araştırmasında da gelişim ve değerlendirme ile destek alt boyutlarında 
genç okul yöneticilerinin daha düşük puana sahip oldukları görülmektedir. Alanyazında bu sonuçlarla farklılık ihtiva eden bazı araştırmalar da bulunmaktadır. Çetin-Yılmaz (2008), 2140 yaş arasındaki okul yöneticilerinin tüm alt boyutlarda bilgisayar teknolojilerini kullanma yeterlikleri ile 41 yaş ve üzerinde olan okul yöneticilerinin yeterlikleri arasında anlamlı bir fark bulunmadığını söylerken, Terci (2008) de, benzer şekilde, ilköğretim okulu yöneticilerinin yönetici yeterlik düzeylerine ilişkin algılarının yaşa göre anlamlı bir farklılık göstermediğini belirtmiştir. Memişoğlu \& Özsarıkamış’a (2009) göre de ilköğretim okulu yöneticilerinin bilgi yönetimi alt boyutlarında görüşleri arasında yaşlarına göre anlamlı farklılık yoktur. Almış’ın (2010) araştırması incelendiğinde ise okul yöneticilerinin bilgiyi yönetme yeterliklerinde; uygun ortam oluşturma, bilgiyi elde etme/üretme, bilgiyi depolama, bilgiyi paylaşma ve bilgiyi kullanma boyutları yönünden yaşlarına göre istatistiksel olarak anlamlı farklılık bulunmamıştır.

Okul yöneticilerinin eğitim durumları, eğitim öğretim işlerini gerçekleştirme düzeylerine ilişkin algılarında istatistiksel olarak anlamlı farklılaşmaya yol açmamaktadır. Terci'nin (2008) araştırmasında yöneticilerin mezun oldukları okul gruplarına göre yönetici yeterliklerine ilişkin algı düzeyleri arasında anlamlı fark bulunmamıştır.

Okul yöneticilerinin HİE almış olmalarının eğitim öğretim işlerini gerçekleştirme düzeylerine ilişkin algılarında istatistiksel olarak anlamlı farka yol açmadığı sonucuna ulaşılmıştır. Terci'nin (2008) araştırmasında, yöneticilikle ilgili kursa katılıp katılmama bakımından, yöneticilerin yönetici yeterlik davranışlarına ilişkin algıları arasında eğitime katılan yöneticiler lehine istatistiksel olarak anlamlı fark bulunmuştur. Çetin-Yılmaz'ın (2008) yaptığı çalışmanın sonuçlarına göre HİE alan ve almayan okul yöneticilerinin eğitim ve öğrenci işlerinde bilgisayar teknolojilerini kullanma düzeyleri arasında, HİE alan okul yöneticileri lehine anlamlı bir fark bulunmuştur. Bunun yanı sıra hizmet içi eğitim alan ve almayan okul yöneticilerinin işgören işlerinde, okul işletmesi ile ilgili işlerde bilgisayar teknolojilerini kullanma yeterlikleri ve genel olarak bilgisayar teknolojilerini kullanma yeterlikleri arasında anlamlı bir farklılık bulunmamıştır.

Okul Yöneticilerinin Teknoloji Liderliği Özyeterlik Algılan ile Ĕ̆itim Öğretim İşlerini Gerçekleştirme Düzeylerine İlişkin Algıları Arasındaki İlişki

Araştırmanın sonuçları incelendiğinde, okul yöneticilerinin teknoloji liderliği özyeterlikleri ile eğitim öğretim işlerini gerçekleştirme düzeylerine ilişkin algıları arasındaki ilişkinin genel toplamda ve diğer tüm alt boyutlarda pozitif yönde orta düzeyde ve anlamlı 
olduğu görülmüştür. Bulgular 1şığında okul yöneticilerinin teknoloji liderliği özyeterlikleri arttıkça eğitim öğretim işleri gerçekleştirme düzeylerine ilişkin algılarının da arttığ sonucuna ulaşılabilir. Bu durum okul yöneticilerinin, rutin eğitim öğretim işlerini gerçekleştirirken teknolojiyi kullanma becerilerinin artmasıyla işlerinin daha kolaylaşacağ şeklinde bir algıya sahip oldukları şeklinde de yorumlanabilir. Baş (2012) ise, ilköğretim okulu yöneticilerinin teknoloji liderliği rolleri, okulda oluşturulan tüm eğitim öğretim işleri ve okul iklimi arasında anlamlı bir ilişki olmadığını söylemektedir.

$\mathrm{Bu}$ araştırma sonucunda elde edilen veriler incelendiğinde, okul yöneticilerinin eğitim öğretim işlerini gerçekleştirme düzeylerini, teknoloji liderliği özyeterliklerinin anlamlı bir şekilde yordadığı sonucuna ulaşılmıştır. Bu durum okul yöneticilerinin teknoloji liderliği özyeterliklerinin de, eğitim öğretim işlerini gerçekleştirme düzeylerine ilişkin algılarını açıklayan bir boyut olarak ele alınabileceği şeklinde yorumlanabilir. Örneğin, eğitim öğretim işlerinde teknoloji kullanımı açısından başarılı öğretmenlerin izlenip desteklenmesi, tüm öğreticilerin hizmetiçi eğitime katılmaları konusunda teşvik edilmesi, istekli olmayanlara model olması, diğer okullardaki başarılı uygulamaları takip etmesi ve benzer yenilikleri kendi kurumuna aktarmada öncülük etmesi, okuldaki teknolojik altyapı ve sorunların ivedilikle çözümlenmesi ve güncellenmesi, okul kütüphanesinin teknolojik imkanlarla donatılması, öğrencilerin bu teknolojilere erişimlerinde kısıtlamalara gidilmemesi ve hatta erişim şansı az olan öğrencilere ekstra zamanlamalar yapılması, öğrenci ve öğretmenleri bir araya getirecek sosyal boyutlu teknoloji ile desteklenen etkinlikler düzenlemesi, başarılı öğrencilerin ödüllendirilmesi, öğretmen ve öğrencilerin yanı sıra diğer çalışanlar ve veliler ile, kısacası tüm paydaşlarla aktif biçimde teknoloji destekli işbirliği kurarak iletişim halinde olmaları..vb. süreçlerde liderlik etmeleri beklenmektedir. Eren \& Kurt (2011)'in araştırmasında okul müdürleri ile doğrudan görüşme yoluna gidilmiş ve okul müdürlerinin eğitim teknolojileriyle ilgili stratejik hedefler belirleme, bu teknolojileri alırken paydaşlarla işbirliği yapma ve mali açıdan destekler araştırma, eğitim öğretimde teknoloji kullanımını teşvik etme, bunun için gerekli hizmetiçi eğitimleri almaları konusunda öğretmenleri destekleme ve okulun mevcut donanımları için teknik destek bulma rollerini gerçekleştirmeye çalıştıkları görülmüştür. 


\section{Öneriler}

$\mathrm{Bu}$ kısımda, okul yöneticilerinin teknoloji liderliği özyeterlikleri ve eğitim öğretim işlerini gerçekleştirme düzeylerine ilişkin algılarını belirlemek amacıyla gerçekleştirilen bu çalışmanın araştırma sonuçlarından geliştirilen öneriler yer almaktadır.

\section{Araştırmacılar için Öneriler}

1. Okul yöneticilerinin kendi algılarına ek olarak, beraber çalıştıkları öğretmenler gözüyle de durum tespiti için Türkiye genelinden örneklem seçilip, her iki gruptan da veri toplayarak yeni bir araştırma yapılabilir.

2. Okul yöneticilerinin çağın tüm teknolojileri ile uyumlu çalışabilmeleri ve eğitim yönetiminde bu kaynaklardan optimum düzeyde yararlanabilmeleri için bilimsel inceleme/değerlendirmeler yapılarak, hazır bulunuşluk düzeyleri belirlenerek ihtiyaç analizi yapılabilir.

3. Başarılı okullar tespit edilip bu okulların yönetici ve öğretmenleri çeşitli yönlerden (teknoloji liderliği ve eğitim öğretim işlerini gerçekleştirme düzeyleri) araştırılabilir.

\section{Uygulayıcılar için Öneriler}

1. Okul yöneticilerine yönetim becerilerini arttırmak amacıyla teknoloji liderliği konularında hizmet içi eğitim verilebilir.

2. MEB tarafından başarılı teknoloji uygulamalarının gerçekleştirildiği okullar izlenerek, bu uygulamaların diğer okullara tanıtılması amacıyla etkinlikler düzenlenebilir.

3. Öğretmenlere okul yöneticilerinin teknoloji liderliği konusunda yapması gerekenler hakkında hizmet içi eğitim verilebilir.

4. Üniversitelerin de desteği ile yöneticilere bilgi ve iletişim araç gereçlerini tanıtan, kullanmayı teşvik edici uzmanlık düzeyinde dersler verilip, projeler yürütülerek, bu teknolojileri profesyonel biçimde işe koşabilen yöneticiler yetiştirilebilir.

\section{Kaynaklar}

Ada, Ş., Görgülü, D., \& Küçükali, R. (2013). Okul yöneticilerinin teknolojik liderlik özyeterliliği. Eğitim Teknolojisi Kuram ve Uygulama, 3(2), 53-71.

Ağaoğlu, E. Altınkurt, Y. Yılmaz K., \& Karaköse, T. (2012). Okul yöneticilerinin yeterliklerine ilişkin okul yöneticilerinin ve öğretmenlerin görüşleri (kütahya ili örneği). Eğitim ve Bilim Dergisi, 37 (164), 159-175.

Akbaba-Altun, S., \& Gürer, M. (2008). İlköğretim okulu yöneticilerinin bilgi teknolojisi (BT) sınıflarına yönelik rollerine ilişkin algıları. Eurasian Journal of Educational Research, 33, 35-54. 
Aksoy, Ş. (2012). İlköğretim okulu müdürlerinin yeterlikleri ile eğitim-öğretim süreci arasındaki ilişki. Yayımlanmamış doktora tezi. Gazi Üniversitesi Eğitim Bilimleri Enstitüsü, Ankara.

Almış, S. (2010). Eğitim yöneticilerinin bilgi yönetimine ilişkin yeterlikleri (Sinop İli Örneği). Yayımlanmamış yüksek lisans tezi. Ondokuz Mayıs Üniversitesi Sosyal Bilimler Enstitüsü, Samsun.

Anderson, R.E., \& Dexter, S. (2005). School technology leadership: an empirical investigation of prevalence and impact. Educational Administration Quarterly, 41 (1), 49-82.

Aydoğan, İ. \& Helvacı, M. A. (2011). Etkili okul ve etkili okul müdürüne ilişkin öğretmen görüşleri. Uşak Üniversitesi Sosyal Bilimler Dergisi, 4(2), 41-60.

Aypay, A. Balıkçı, A., \& Şahin, M. (2013). 2012 yılında kabul edilen eğitim reformunun okul yöneticiliği üzerine yansımaları nasıl olmuştur? 8. Ulusal Eğitim Yönetimi Kongresi, 7-9 Mayıs, İstanbul.

Banoğlu, K. (2009). İlköğretim okullarında görev yapmakta olan yönetici ve öğretmenlerin öğrenen örgüt algısı. Yayınlanmamış yüksek lisans tezi, Yıldız Teknik Üniversitesi, Sosyal Bilimler Enstitüsü, İstanbul.

Baş, E. D. (2012). Illköğretim okulu yöneticilerinin teknoloji liderliği rolleriyle okul iklimi arasındaki ilişki. Yayımlanmamış yüksek lisans tezi. Maltepe Üniversitesi Sosyal Bilimler Enstitüsü, İstanbul.

Bostanc1, H. (2010). Okul yöneticilerinin teknolojik liderlik yeterlikleri açısından incelenmesi. Yayımlanmamış yüksek lisans tezi. Gazi Üniversitesi Bilişim Enstitüsü, Ankara

Bülbül, T. \& Çuhadar, C. (2012). Okul yöneticilerinin teknoloji liderliği özyeterlik algıları ile bilgi ve iletişim teknolojilerine yönelik kabulleri arasındaki ilişkinin incelenmesi. Mehmet Akif Ersoy Üniversitesi Ĕ̆itim Fakültesi Dergisi, 12(23), 474-499.

Büyüköztürk, Ş. Çakmak, E. E., Akgün, Ö. E., Karadeniz, Ş., \& Demirel, F. (2010). Bilimsel araştırma yöntemleri. Ankara: Pegem A Yayıncılık.

Can, T. (2003). Bolu orta öğretim okulları yöneticilerinin teknolojik liderlik yeterlikleri. The Turkish Online Journal of Educational Technology (TOJET), 2 (3), 94-107

Can, T. (2008). İlköğretim okulları yöneticilerinin teknolojik liderlik yeterlikleri: Ankara İli Etimesgut İlçesi Örneği. In proceedings of VIII. International Educational Technology Conference, 1053-1057, Eskişehir.

Çalık, T. \& Şirin, H. (2007). Eğitim ile ilgili hizmetler. Servet Özdemir (Editör). Türk eğitim sistemi ve okul yönetimi.(s. 189-199) Ankara: Nobel Yayın Dağıtım.

Çetin-Yılmaz, S. (2008). İlköğretim okulu yöneticilerinin bilgisayar teknolojisini kullanma yeterliklerinin değerlendirilmesi. Yayınlanmamış yüksek lisans tezi, Gazi Üniversitesi Eğitim Bilimleri Enstitüsü, Ankara.

Çevik, V. (2006). Eğitim yöneticileri ile yönetici adaylarının kaygı düzeyleri ile bilgisayar kaygısı düzeylerinin karşılaştırılması. Yayınlanmamış yüksek lisans tezi, Gaziosmanpaşa Üniversitesi Sosyal Bilimler Enstitüsü, Tokat.

Deming, E.W. (1998). Krizden çıkış (Çev. C. Akaş). Kalder Yayınları.

Eren, E. (2007). Örgütsel davranış ve yönetim psikolojisi, İstanbul: Beta. 
Eren, E. \& Kurt, A. A. (2011). İlköğretim okul müdürlerinin teknoloji liderliği davranışları. Uşak Üniversitesi Sosyal Bilimler Dergisi, 4(2), 219-238.

Ergişi, K. (2005). Bilgi teknolojilerinin okulda etkin kullanımı ile ilgili okul yöneticilerinin teknolojik yeterliklerinin belirlenmesi (Kırıkkale ili örneği). Yayınlanmamış yüksek lisans tezi, Kırıkkale Üniversitesi, Kırıkkale.

Gürbüz, R. Erdem, E., \& Yıldırım, K. (2013). Başarılı okul müdürlerinin özellikleri. Dicle Üniversitesi Ziya Gökalp Ĕ̆itim Fakültesi Dergisi, 20, 167-179

Hacıfazlığ̆lu, Ö. Karadeniz, Ş., \& Dalgıç, G. (2010). Eğitim yöneticileri teknoloji liderliği standartlarına ilişkin öğretmen, yönetici ve denetmenlerin görüşleri. Kuram ve Uygulamada Ĕ̆itim Yönetimi, 16(4), 537-577

Hacıfazlıŏ̆lu, Ö. Karadeniz, Ş., \& Dalgıç, G. (2011a). Eğitim yöneticileri teknoloji liderliği özyeterlik ölçeğinin geçerlik ve güvenirlik çalışması. Kuram ve Uygulamada Ĕ̆itim Yönetimi, 17(2),145-166

Hacıfazlığlu, Ö. Karadeniz, Ş., \& Dalgıç, G. (2011b). Okul yöneticilerinin teknoloji liderliğine ilişkin algıları: metafor analizi örneği. Eğitim Bilimleri Araştırma Dergisi, 1(1), 97-121

Hayytov, D. (2013). Eğitim yöneticilerinin teknoloji liderliği yeterlik algılar ile öğretmenlerin teknolojiye yönelik tutumları arasındaki ilişki. Yayınlanmamış yüksek lisans tezi, Gazi Üniversitesi Eğitim Bilimleri Enstitüsü, Ankara.

ISTE (2009). NETS for administrators 2009. http://www.iste.org/docs/pdfs/2014_ ISTE_Standards A_PDF.pdf, 20/06/2014 tarihinde alınd1.

Karasar, N. (2008). Bilimsel araştırma yöntemi", Ankara: Nobel Yayın Dağıtım.

Memişoğlu, S. P. \& Özsarıkamış, S. (2009). İlköğretim okulu yöneticilerinin bilgi yönetimi yeterlikleri. Abant İzzet Baysal Üniversitesi Dergisi, 9(2), 133-151.

Sezer, B. \& Deryakulu, D. (2012). İlköğretim okul yöneticilerinin teknoloji liderliği rollerine ilişkin yeterlikleri. Ĕgitim Teknolojisi Kuram ve Uygulama, 2(2), 74-92.

Sincar, M. (2009). "İlköğretim okulu yöneticilerinin teknoloji liderliği rollerine ilişkin bir inceleme". Yayınlanmamış doktora tezi. İnönü Üniversitesi Sosyal Bilimler Enstitüsü, Malatya.

Şişman-Eren, E. (2010). İlköğretim okul müdürlerinin eğitim teknolojilerini sağlama ve kullanmada gösterdikleri liderlik davranışları. Yayınlanmamış doktora tezi. Anadolu Üniversitesi Eğitim Bilimleri Enstitüsü, Eskişehir.

Tanzer, S. (2004). Mesleki ve teknik öğretim okul yöneticilerinin teknolojik liderlik. Yayımlanmamış yüksek lisans tezi, Abant İzzet Baysal Üniversitesi Sosyal Bilimler Enstitüsü, Bolu.

Terci, F. (2008). İlköğretim okulu yöneticilerinin yönetici yeterlik davranışlarının bazı değişkenler açısından incelenmesi. Yayınlanmamış yüksek lisans tezi, Ege Üniversitesi Sosyal Bilimler Enstitüsü, İzmir.

Telem, M. (1991). A Knowledge-Base for Information Technology in Educational Administration. Journal of Research on Computers in Education, 23, 594-610.

Turan, S. (2002). Teknolojinin okul yönetiminde etkin kullanımında eğitim yöneticisinin rolü. Kuram ve Uygulamada Ĕ̆itim Yönetimi, 30, 271-281.

Yıldırım, N. (2008). İlköğretim okulu müdürlerinin öğretmenleri güdüleme düzeylerine ilişkin öğretmenlerin ve okul müdürlerinin görüşleri (Tokat ili örneği). Doğu Anadolu Bölgesi Araştırma ve Uygulama Merkezi, 6(2). 132-140. 
EK 1. Okul Yöneticilerinin Teknoloji Liderliği Özyeterlikleri ile Ĕ̆itim Öğretim İşlerini Gerçekleştirme Düzeyleri Arasındaki İlişki

\begin{tabular}{|c|c|c|c|c|c|c|c|c|c|c|c|c|c|c|}
\hline \multicolumn{15}{|c|}{ Yöneticiler (n= 112) } \\
\hline & & 1 & 2 & 3 & 4 & 5 & 6 & 7 & 8 & 9 & 10 & 11 & 12 & 13 \\
\hline 1 & Politikalar ve sosyal etkinlikler & & & & & & & & & & & & & \\
\hline 2 & Öğretimin Geliştirilmesine Yönelik Destekleyici Hizmetler & $.80^{* *}$ & & & & & & & & & & & & \\
\hline 3 & $\begin{array}{l}\text { Eğitim-Öğretimin Geliştirilmesine Yönelik Yönetim } \\
\text { Görevleri }\end{array}$ & $.78^{* *}$ & $.82^{* *}$ & & & & & & & & & & & \\
\hline 4 & Rehberlik Hizmetleri & $.57^{* *}$ & $.75^{* *}$ & $.74^{* *}$ & & & & & & & & & & \\
\hline 5 & Etkililik ve Düzenlilik & $.63^{* *}$ & $.76^{* *}$ & $.76^{* *}$ & $.71^{* *}$ & & & & & & & & & \\
\hline 6 & Gelişim ve değerlendirme & $.73^{* *}$ & $.79^{* *}$ & $.75^{* *}$ & $.71^{* *}$ & $.76^{* *}$ & & & & & & & & \\
\hline 7 & Eğitim öğretim işleri gerçekleştirme düzeyleri toplamı & $.90^{* *}$ & $.95^{* *}$ & $.92^{* *}$ & $.79^{* *}$ & $.83^{* *}$ & $.84^{* *}$ & & & & & & & \\
\hline 8 & Vizyoner liderlik & $.40^{* *}$ & $.34^{* *}$ & $.46^{* *}$ & $.22^{*}$ & $.34^{* *}$ & $.35^{* *}$ & $.41^{* *}$ & & & & & & \\
\hline 9 & Dijital çağ öğrenme kültürü & $.44^{* *}$ & $.48^{* *}$ & $.49^{* *}$ & $.41^{* *}$ & $.44^{* *}$ & $.47^{* *}$ & $.51^{* *}$ & $.74^{* *}$ & & & & & \\
\hline 10 & Profesyonel uygulamada mükemmellik & $.43^{* *}$ & $.40^{* *}$ & $.46^{* *}$ & $.37^{* *}$ & $.41^{* *}$ & $.47^{* *}$ & $.47^{* *}$ & $.74^{* *}$ & $.74^{* *}$ & & & & \\
\hline 11 & Sistematik gelişim & $.42^{* *}$ & $.37^{* *}$ & $.47^{* *}$ & $.38^{* *}$ & $.38^{* *}$ & $.42^{* *}$ & $.45^{* *}$ & $.63^{* *}$ & $.69^{* *}$ & $.75^{* *}$ & & & \\
\hline 12 & Dijital vatandaşlık & $.54^{* *}$ & $.42^{* *}$ & $.51^{* *}$ & $.31^{* *}$ & $.38^{* *}$ & $.48^{* *}$ & $.51^{* *}$ & $.62^{* *}$ & $.65^{* *}$ & $.67^{* *}$ & $.71^{* *}$ & & \\
\hline 13 & Teknoloji liderliği özyeterlik algıları toplamı & $.51^{* *}$ & $.47^{* *}$ & $.55^{* *}$ & $.40^{* * *}$ & $.45^{* *}$ & $.51^{* *}$ & $.55^{* *}$ & $.84^{* *}$ & $.89^{* *}$ & $.89^{* *}$ & $.85^{* *}$ & $.85^{* *}$ & \\
\hline
\end{tabular}

** $\mathrm{p}<.01$ 